\title{
CURRENT SCENARIO OF THE PANDEMIC COVID-19: AN OVERVIEW
}

\section{Utsang Kumar, Shailja Singhal, Rekha Khandia*, Ashok Munjal}

Department of Biochemistry and Genetics, Barkatullah University, Bhopal, Madhya Pradesh, India

Received - September 14, 2020; Revision-October 28, 2020; Accepted - November 02, 2020

Available Online November 08, 2020

DOI: http://dx.doi.org/10.18006/2020.8(Spl-1-SARS-CoV-2).S158.S175

KEYWORDS
Coronavirus
SARS-CoV-2
COVID-19
SARS-CoV
MERS-CoV
ACE-2
ARDS
RdRp (RNA dependent RNA
polymerase)

polymerase)

\begin{abstract}
The novel coronavirus disease-19 (COVID-19) caused by the SARS-CoV-2 is an emerging disease with deadly consequences, extended its stride over the globe commenced from the epicenter, Wuhan wet market, China led to declare globally as pandemic disease. Several non-specific features of the disease like prolonged incubation period, asymptomatic yet contagious, longer illness duration, and conveyance post clinical recovery feature makes prevention difficult and is the key reason for its rapid spread across the world. Covid-19 shows varied manifestations with the majority of reported cases having mild or even no symptoms. However, the infection led to a destructive footprint in the pulmonary system, specifically, lungs are most prone to damage, making them incapable of conducting respiratory functions and thus, resulting in acute respiratory distress syndrome (ARDS), multi-organ dysfunction, and loss of life. Up to the present, there is no worldwide-approved treatment for COVID-19 and only repurposed drugs are employed for the hospitalized patient, necessitating an urgent need to develop effective therapeutics. Hence, effective control of disease spread through screening and isolation of contacts is crucial in the community. The contagion effect of the COVID-19 outbreak has brought major challenges to health systems as well as global economy worldwide. Development of rapid diagnostic test and effective vaccine as well as minimizing the exposure of the human population to possible animal reservoirs is measures needed to curb future impact. The outbreak of SARS-CoV in 2003 followed by MERS-CoV within a decade, indicates the threat of novel infectious diseases resulting from RNA viruses, will continue to present a serious global health threat, as epitomized by COVID-19. Therefore, this review is attempting to provide an overview of the current scenario of COVID-19 in terms of epidemiology, pathophysiology, diagnosis, prevention, and treatment, especially focusing on public health impact.
\end{abstract}

* Corresponding author

E-mail: rekha.morchhale@gmail.com (Rekha Khandia)

Peer review under responsibility of Journal of Experimental Biology and Agricultural Sciences.

Production and Hosting by Horizon Publisher India [HPI] (http://www.horizonpublisherindia.in/).

All rights reserved.
All the articles published by Journal of Experimental Biology and Agricultural Sciences are licensed under a Creative Commons Attribution-NonCommercial 4.0 International License Based on a work at www.jebas.org.

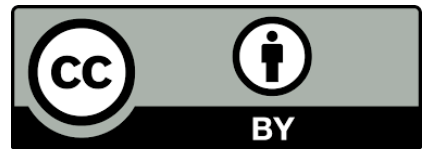




\section{Introduction}

The year 2020 is globally declared as public health emergency period by the WHO on March 11, 2020. The deadly novel coronavirus (COVID-19) or the Severe Acute Respiratory Syndrome Corona Virus 2 (SARS-CoV-2) pandemic, which was first reported in December 2019 in Wuhan wet market, located at Wuhan City of Hubei Province of China. The 2019-nCoV is a non-segmented, positive-sense RNA virus with a lipid envelope and belongs to the family Coronaviridae, order Nidovirales that infects both humans and other mammals (Richman et al., 2016). Chinese health authorities did an immediate investigation in order to identify and control the disease, including isolation of suspected persons, close monitoring of contacts, epidemiological and clinical data collection from patients, and development of diagnostic and treatment procedures. Although the epicenter of the COVID-19 outbreak in December of 2019 was in Wuhan City of China, this disease has spread to more than 150 countries with over 3,69,45,310 confirmed cases and over 10,69,513 deaths worldwide as of October 8, 2020 (Coronavirus Outbreak, 2020). In India, 69,57,511 cases have been reported to date (Coronavirus Outbreak, 2020). As compared to previous human CoV outbreaks, COVID-19 is showing a higher rate of disease conveyance but of less pathogenicity, as obviously the number of confirmed cases increasing throughout the globe (Dhama et al., 2020a). In addition, millions of people's lives have been affected as a result of mandatory isolations/quarantines. The contagion effect of the COVID-19 outbreak has potentially brought major challenges to worldwide health systems and the global economy since the infection is not effectively controlled. Hence, this virus has brought global disaster. Therefore, this review is attempting to present a picture of coronavirus disease (COVID-19) in terms of epidemiology, pathophysiology, mechanism of infection and immunity, diagnosis, and treatment on the basis of available literature especially focusing on public health impact. This review will detail the most current clinical and epidemiological findings to the ongoing pandemic.

\section{History}

Coronaviruses are positive-sense, single-stranded RNA viruses ranging from $60 \mathrm{~nm}$ to $140 \mathrm{~nm}$ in diameter and having the largest viral genome (26-32kb) among the RNA viruses that replicate using a nested ("Nido") set of mRNAs (Richman et al., 2016; Zhang et al., 2018; Florindo et al., 2020). The family Coronaviridae consists of two genera, Torovirus and Coronavirus that have further subdivisions in four groups; alpha, beta, delta, and gamma CoVs by phylogenetic clustering (Zhang et al., 2018). The genome analysis of the initial genomic sequence of the ongoing pandemic-causing virus did not match with previously known human CoVs sequences, inferring a novel CoV strain (COVID-19) (Dhama et al., 2020a). The virus underlying COVID-19 (SARS-CoV-2) is a betacoronavirus that is closely related to SARS-CoV (share $\sim 80 \%$ RNA sequence identity) (Morse et al., 2020). The betacoronavirus genome encodes several structural proteins, including envelope (E), membrane (M), nucleocapsid $(\mathrm{N})$, and the glycosylated spike (S) protein. The glycosylated spike (S) protein is a multifunctional class I viral transmembrane protein and functions as a major inducer of host immune responses (Dhama et al., 2020a). Host cell invasion by both SARS-CoV (SARS related coronaviruses) and SARS-CoV-2 via binding to a receptor protein called angiotensin-converting enzyme 2 (ACE2) located on the surface membrane of host cells though $\mathrm{S}$ protein has been reported (Du et al., 2009; Baez-Santos et al., 2015; Hoffmann et al., 2020; Liu et al., 2020a; Wrapp et al., 2020). The glycoprotein spike is responsible for attachment to human cell and the projections present on the surface of viral membrane gives it a crown-like appearance; hence named as coronavirus (Richman et al., 2016; Singhal et al., 2020). Coronaviruses have been identified in mammals and birds like; humans, mice, alpacas, horses, dogs, cattle, chicken, swine, bats, etc. (Zhang et al., 2018). They may cause a variety of diseases including gastroenteritis and respiratory tract infection, etc. (Gerna et al., 2006) while in humans, coronaviruses $(\mathrm{HCoV})$ are proven to cause respiratory tract infection such as sore throat, runny nose, or prominent respiratory tract problems like ARDS, SARS and MERS (Bao et al., 2020). SARS-CoV-2 is genetically related to SARS-CoV, which caused a global epidemic with 8096 confirmed cases and 774 casualties reported worldwide and the various Asian-Pacific countries during the year 2002-2003 (Summary of probable SARS cases with onset of illness, Geneva: World Health Organization, 2004; Chan-Yeung \& Xu, 2003). The Guangdong province of China in 2002-2003 was badly affected by a new coronavirus of the $\beta$ genera (SARS) and with origin in bats crossed over to humans via the intermediary host of palm civet cats. This virus affected 8422 people mostly in China and Hong Kong and caused 916 casualties with a mortality rate of $11 \%$ before being contained (Chan-Yeung \& Xu, 2003). Almost a decade later in 2012, the outbreak of MERS-CoV (MERS related coronaviruses), also of bat origin with dromedary camels as the intermediate host, in Saudi Arabia affected 2494 people and caused 858 deaths with a mortality rate of 34\% (Chan-Yeung \& Xu, 2003; Middle East Respiratory Syndrome Coronavirus, 2020). Four human coronaviruses (HCoVs) namely OC43, 229E, NL63, and HKU1 have been detected during 2010-2015 in Guangzhou, prevalent in the human population that generally cause mild respiratory disease, and among the positive cases OC43 HCoV were found relatively in a higher degree (Zhang et al., 2018). Human coronaviruses reported since 2003 are enlisted in Table 1. The novel coronavirus disease-19 (COVID-19) has spread to more than 150 countries with India being in the second position among the most hit countries as of October 8, 2020 (Coronavirus Outbreak, 2020). Figure 1(a) and 1(b) represents total number of infected people and casualties in various countries till date. Figure 2 represents the total number of infected since outbreak along with active and recovered cases among the 20 most hit countries countries (as per data available till October 8, 2020). 
Table 1: Human coronaviruses (HCoVs) reported since 2003, with fatality rate, death toll, reported cases and current circulation.

\begin{tabular}{|cccccccc|}
$\begin{array}{c}\text { Types of } \\
\text { HCoVs }\end{array}$ & $\begin{array}{c}\text { Outbre } \\
\text { ak Year }\end{array}$ & $\begin{array}{c}\text { Emergent/Previously } \\
\text { Circulating }\end{array}$ & $\begin{array}{c}\text { Fatality } \\
\text { Rate }\end{array}$ & $\begin{array}{c}\text { Death } \\
\text { toll }\end{array}$ & Reported Cases & $\begin{array}{c}\text { Current } \\
\text { Circulation }\end{array}$ \\
\hline SARS-CoV & 2003 & Emergent & $\sim 10 \%$ & 916 & $>8000$ & No \\
\hline HCoV-NL63 & 2003 & Previously circulating & low & NA & NA & Yes \\
\hline HCoV-HKU1 & 2004 & Previously circulating & low & NA & NA & Yes \\
\hline MERS-CoV & 2012 & Emergent & $\sim 30 \%$ & 817 & 2274 & Yes \\
\hline $\begin{array}{c}\text { nCoV-19 } \\
\text { (Till 9:00 pm 8 Oct })\end{array}$ & 2019 & Emergent & $\sim 2-4 \%$ & $10,69,513$ & $3,69,45,310$ & Yes \\
\hline
\end{tabular}

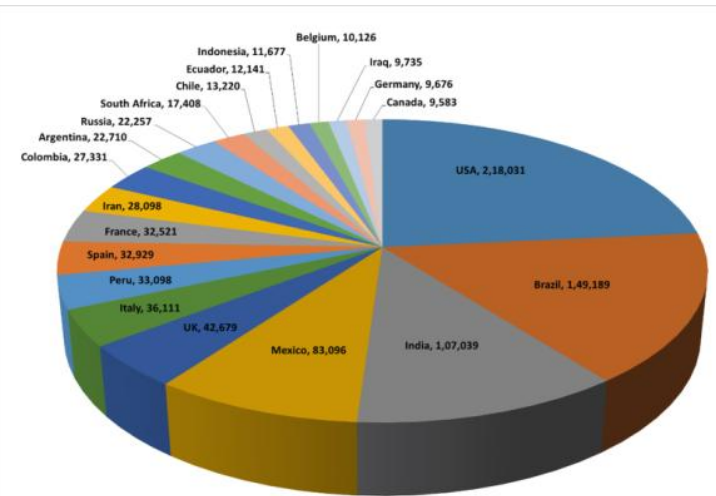

COUNTRIES WITH MORTALTY COUNT

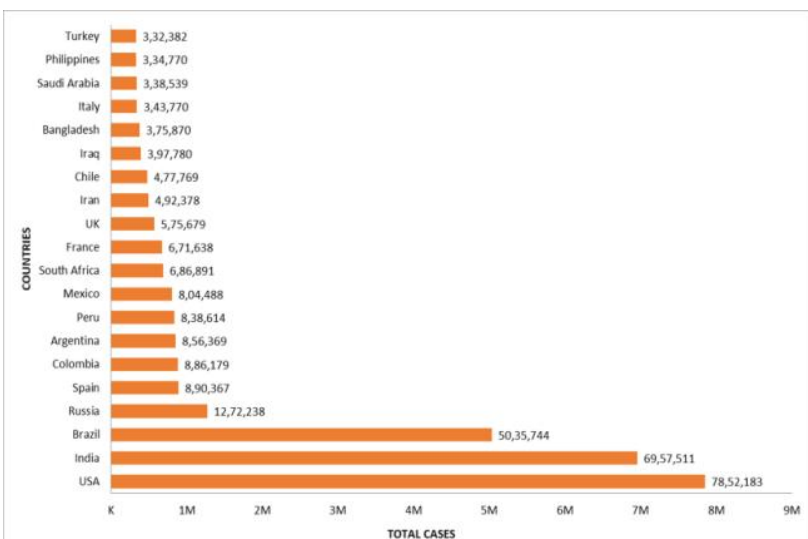

totalcases

Figure 1(a) Total reported cases of SARS-CoV-2 among 20 worst hit countries. [Data as of 09.10.2020, collected from https://www.worldometers.info/coronavirus/]

Figure 1(b) Pie chart of total reported deaths due to SARS-CoV-2 infection among 20 worst hit countries. [Data as of 09.10.2020, collected from https://www.worldometers.info/coronavirus/]

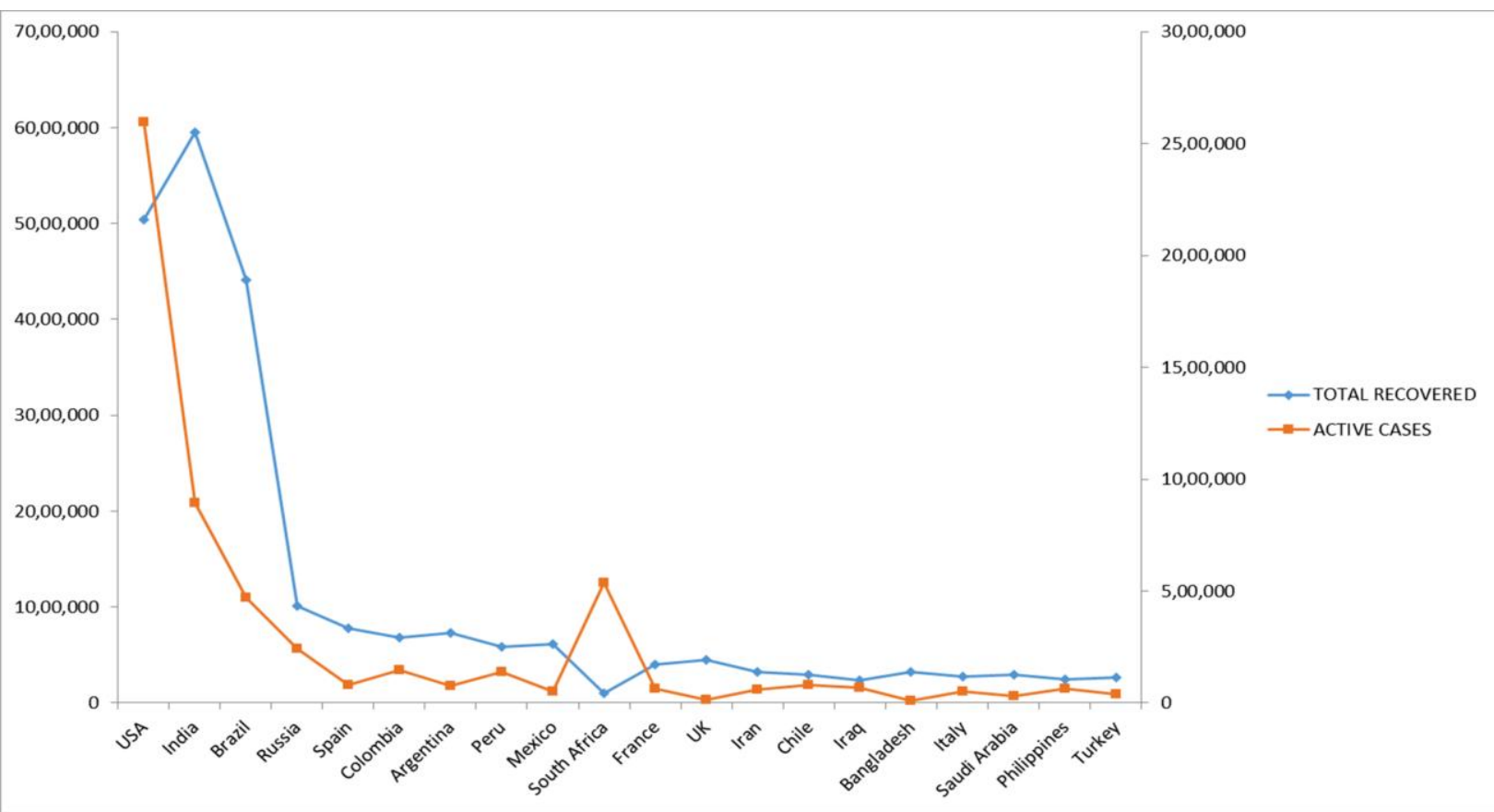

Figure 2 Graphical representation of total reported active and recovered cases of SARA-CoV-2 infection among 20 worst hit countries. Active cases are represented in orange colour and recovered cases in blue. [Data as of 09.10 .2020 , collected from

https://www.worldometers.info/coronavirus/]

Journal of Experimental Biology and Agricultural Sciences

http://www.jebas.org 


\section{Origin and Spread of SARS-CoV-2}

In China in the city of Wuhan, adult Patients started presenting to local hospitals with severe pneumonia of unknown etiology in December 2019 following a total of 44 case-patients were reported to WHO by the national authorities in China. Many of them were exposed to Huanan wholesale seafood market involved in trading of live animals. During this reported period, the causal agent was not identified. The surveillance system was put into action and three bronchoalveolar lavage samples were collected from a patient. Real-time PCR (RT-PCR) assays on these samples indicated a positive match corresponding to pan-betacoronavirus (WHO-China joint mission on COVID-19 final report, 2020). On 7th January the virus was identified as a coronavirus that had $>95 \%$ homology with the bat coronavirus and $>70 \%$ similarity with the SARS-CoV. Bioinformatic analyses inferred that the virus had features typical to the coronavirus family and belonged to the Betacoronavirus. The incidences of infection started increasing exponentially in other parts of China as well as other countries including Thailand, Japan, and South Korea in quick succession. Some health-care workers had also been infected in Wuhan, inferring occurrence of human-to-human transmission (Huang et al., 2020). The Wuhan City was placed under lockdown with restrictions of entry and exit from the region by 23rd January in order to restrain the infection. India along with several other countries initiated the screening measures in order to detect symptomatic people returning from China and those who tested positive for COVID-19 were quarantined. Soon it was realized that asymptomatic people also may play role in spreading infection. Countries including India started placing in isolation for 14 days to all immigrant people following the COVID-19 test. Here it is noteworthy that though the number of new cases has reduced in China lately, it increased exponentially in other countries including South Korea, Italy, Iran, India, Brazil, Russia, and United States. The less number of active cases could be attributed to the underestimation of the infected patients, limitations of surveillance and testing system, and community spread. In Europe, Italy and Spain were badly hit during the early outbreak of the pandemic, with peaks starting in the second half of February 2020 and 61,507 deaths reported by mid of June (Ellinghaus \& Karlsen, 2020). Though recent studies showed that SARS-CoV-2 was likely originated from bats, its intermediate hosts are still largely uncertain. A recent study based on complete genome analysis and phylogenetic analysis suggested that pangolins are natural hosts of coronaviruses and are genetically related to the SARS-CoV-2 but do not justify the direct emergence (Florindo et al., 2020). It requires further evidence whether pneumonia caused by SARSCoV-2 is transmitted directly from bats or through phylogenetically supported intermediate hosts. Further study including the source of the viral transmission and study based on parameters that define virus and host relatedness in terms of codon usage will help to determine zoonotic transmission patterns (Khandia et al., 2019; Perlman, 2020). Information regarding potential hosts may be useful in minimizing the exposures of the human population and will be important in identifying various preventive measures. This will reduce the spillover risks of coronaviruses from wild animals to humans. In addition, the study might also be helpful in the identification of the aptest experimental animal models for vaccine candidate and pathogenicity-associated experiments (Khandia et al., 2019). The phylogenetically supported possible spread of the pandemic among the human population has been represented in Figure 3.

\section{Epidemiology and Pathogenesis}

In Southern China (November 2002) and Hong Kong (February 2003), an outbreak of SARS disease caused by coronavirus originated from contaminated sewage found in Hong Kong affected over 300 residents and transmitted through contact of infected surfaces either by droplets or direct inoculation. At that time this disease spread globally from epicentre Hong Kong via asymptomatic air travellers after a prolonged incubation period, affecting all age groups mainly females. There were global cumulative 8422 cases with 916 deaths (fatality rate of $11 \%$ ) at the end of the epidemic reported. Steps taken for effective control of transmission includes early detection, strict isolation, and quarantine of contacts, contact precautions, and use of personal protective equipment (Chan-Yeung \& Xu, 2003).

For investigating the epidemiological and genetic variation of $\mathrm{HCoV}$, Zhang and his colleagues collected a total of 13048 throat and nasal swab specimens from Guangzhou, South China comprising adults and children with fever and acute upper respiratory infection symptoms and performed screening via RTPCR. The result revealed that on basis of age distribution, children ( $<3$ years old) and old people ( $>50$ years) were both high-risk groups, susceptible to get infected by $\mathrm{HCoV}$ (Zhang et al., 2018).

On December 31, 2019, in Hubei province China, a large number of pneumonia cases of unknown origin were reported, following Wuhan Municipal Health Commission issued an alert and WHO was notified regarding the same. Further investigation connects the spread of this disease from Wuhan's Huanan Seafood Wholesale Market, a well-known meat market. A case study during the early outbreak in epicenter Wuhan city showed the median age of patients among 41 admitted cases were of 49 years in which most of them had a history of chronic diseases like diabetes, hypertension, and cardiovascular diseases. Out of them, 25 patients were reported with severe illness, and the other 6 died (Huang et al., 2020). COVID-19 shows varied manifestations with the majority of reported cases having mild or even no symptoms (Wu $\&$ McGoogan, 2020). According to a previous study, the nasal cavity consists of higher viral loads in comparison to the throat, however there 


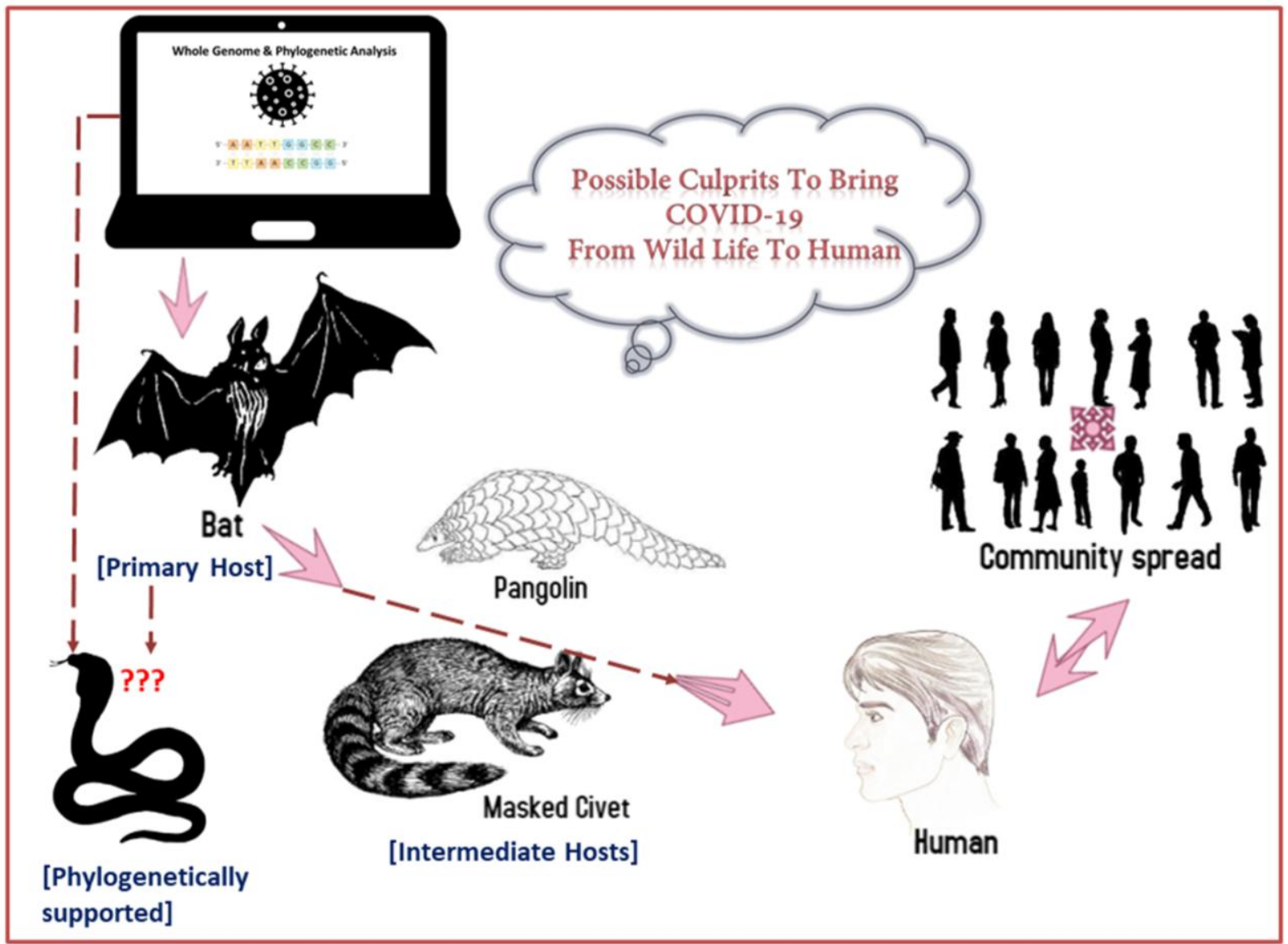

Figure 3 Bioinformatics assists in analysing the whole genome and phylogeny of SARS-CoV-2.

The picture depicts possible mode of transmission from natural host reservoir to human population.

was apparently no difference in viral load amongst symptomatic and asymptomatic people (Zou et al., 2020). Patients can be infectious and may act as super-spreaders until the symptoms last or after clinical recovery also. The main route of transmission is via respiratory droplet transmission, and it can also be transmitted through contact within the range of 1-2 meter where these infected droplets can circulate and deposit on surfaces nearby (Rothe et al., 2020). A healthy person may get infection through inhalation of these droplets or via touching contaminated surfaces. On contaminated surfaces the virus may survive for couple of days under favorable circumstances. Common disinfectants like sodium hypochlorite, hydrogen peroxide, etc. are able to kill virus in less than one minute (Kampf et al., 2020). According to WHO due to the presence of the virus in the stool, it may subsequently cause water supply contamination and further may transmit through aerosol/feco-oral route. Though its transplacental transmission from pregnant women to fetus has not been described but the postnatal transmission was found in some cases (Chen et al., 2020a; Dhama et al., 2020c). According to a study conducted between 27 February 2020 and 30 July 2020 in Denmark to determine the impact of common blood groups on virus vulnerability, individuals with blood group $\mathrm{O}$ might be less vulnerable to SARS-CoV-2 infection in contrast to blood types A, $\mathrm{B}$, or $\mathrm{AB}$, and may offer protection against COVID-19 infection to some extent. However, blood type prevalence may vary considerably in different ethnic groups in different countries. In addition, ABO blood group was not found associated with rates of hospitalization or mortality (Barnkob et al., 2020).

\section{Clinical Features}

The clinical symptoms resulting from COVID-19 are variable, starting from an asymptomatic state to acute respiratory distress syndrome and multi-organ failure. The common symptoms include fever (fever might be completely absent also), dry cough, sore throat, headache, fatigue, myalgia, with or without stuffy nose, rhinorrhoea, and breathlessness. In addition, few patients with COVID-19 infection had prominent respiratory tract problems (eg., rhinorrhoea, sneezing), inferring that the target cells for viral attachment might be located in the lower airway (Singhal et al., 
2020; Huang et al., 2020). In laboratory findings, lymphopenia and bilateral ground-glass opacities or consolidation in chest CT scans have been reported. Similar clinical features have also been reported in previous CoVs; SARS and MERS. The predominant infection site for SARS-CoV-2 is the lower airways, causing the symptoms ranging from mild respiratory illness to acute respiratory distress syndrome (ARDS) following septic shock and acute kidney injury in advanced stages (Cui et al., 2019). In immune-compromised patients, the disease can progress to pneumonia, respiratory failure, and even death also. This condition is associated with an extreme rise in inflammatory cytokines including IL2, IL7, IL10, GCSF, IP10, MCP1, MIP1A, and TNFo (Chen et al., 2020b). Conjunctivitis and intestinal problems (eg. diarrhea) also has been reported in some cases. The mortality is ranging between 4 to $11 \%$ in hospitalized adult patients. Globally the mortality rate is predicted to range between 2 to $4 \%$ (Coronavirus Outbreak, 2020). The Center for Disease Control and Prevention (CDC) has reported the incubation period following infection is of 2-14 days, with an estimated median of 5.1 days (Lauer et al., 2020; Li et al., 2020b). In addition, few cases have been reported with comparatively longer incubation period of 24 days (Bai et al., 2020). The long incubation period has added in massive infection count throughout the globe, as it is mostly asymptomatic yet contagious (Li et al., 2020b).

Patients outside Hubei province have been reported to be mild infection than those from epicenter of the outbreak, Wuhan city (Xu et al., 2020a). This may either be due to the selection bias of the cases reporting from Wuhan where only the severe cases were included or due to predisposition of the Asian population to the virus due to higher expression of ACE2 receptors on the respiratory mucosa (Cheng \& Shan, 2019). The old aged population and particularly those with a long history of chronic diseases or immune compromised people exhibit more severe symptoms after getting the infection. In addition, children and infants are also susceptible but exhibit relatively mild symptoms (Zeng et al., 2020). Death cases are more frequent in the elderly and those with chronic underlying diseases (General Office of National Health Committee (Trial Version 4) 2020).

\section{Diagnosis}

The most common symptoms reported in COVID-19 infected cases are fever, fatigue, and dry cough while few cases appeared with headaches, rhinorrhoea, sore throat, and intestinal problems, etc. All the persons with travel history to China or areas with persistently reported cases of infection, or contact with patient with similar travel history or person with confirmed COVID-19 infection comes under suspected category, while the confirmed case are the one with positive molecular test and such patients could be asymptomatic also. Patients may feel breathlessness, rattling sounds in the lungs, pleural effusions, and abnormal tactile speech tremors, etc. (Jin et al.,2020). Studies have suggested that abnormalities in CT scan (Computed tomography) of the chest are more likely bilateral, have a peripheral distribution involving the lower lobes. However, common findings include pleural thickening, pleural effusion, and lymphadenopathy (Lippi et al., 2020; Lagier et al., 2020). These clinical presentations help in the early detection of infected cases, especially against a background of ongoing influenza and other respiratory illness (Ai et al., 2020). According to a case study, about $30-60 \%$ of total positive cases were found initially by RT-PCR (Ai et al., 2020). The reverse transcriptase-polymerase chain reaction (RT-PCR) is the leading diagnosis process of finding positive nucleic acid of SARS-CoV-2 based on nucleic acid amplification tests (NAAT) in nasal, sputum, throat swab, and secretions of lower respiratory tract samples. The WHO suggested resampling and collection of samples from multiple respiratory sites and a further systematic evaluation for cases with false-negative reports. Another tool for diagnosis might be on the basis WBC counting. Severe symptoms have been associated with lower lymphocyte and higher leukocyte counts. An elevated level of enzymes such as lactate dehydrogenase, aminotransferase, and ferritin is the third tool for diagnosis. Patients with severe lymphopenia symptoms were reported with a sudden increase in procalcitonin level (Ljungström et al., 2017). A sampling of nasopharyngeal swabs is useful, but it shows a relatively high false-negative rate. Secondly, other laboratory tests like blood oxygensaturation analysis, comprehensive metabolic panel (CMP) for liver and kidney function, myocardial enzyme level, erythrocyte sedimentation rate (ESR or Sed Rate), C-reactive protein (CRP), Procalcitonin (PCT) for serious bacterial infection screening, such as sepsis, urinalysis, inflammatory factors IL-6, IL-10, TNF - asubgroup, acid-fast staining, etc. also could be useful (Jin et al., 2020; Liu et al., 2020b).

Recently, the findings of a case study conducted in the Boston, Massachusetts between March 4, 2020, and April 28, 2020, comprising 1641 adult patients of COVID-19 suggested that an elevated red blood cell distribution width (RDW greater than $14.5 \%$ ), which is part of a routine complete blood count component (CBCC) measured at the time of admission and during the period of hospitalization was associated with severe mortality risk. These patients were at 2.7 times higher risk of dying with a mortality rate of $31 \%$ in contrast to patients with normal RDW values (mortality rate $11 \%$ ). The association between RDWmortality risk has been found independent of D-dimer level (dimerized plasmin fragment-D), absolute lymphocyte count (white blood cell) and demographic factors. Thus, RDW may be helpful in patient risk categorization especially during elevated number of hospitalization and mortality (Foy et al., 2020).

In addition, identifying biomarkers associated with higher odds of clinical deterioration and fatality in COVID-19 patients can be helpful in recognizing disease severity and predicting outcomes. 
Biomarkers (IL-6, D-dimer, CRP, LDH, and ferritin) of inflammation and coagulopathy may aid in spotting hospitalized COVID-19 patients at risk for clinical deterioration. Among these biomarkers, LDH (> 1200 units/l) is highly associated with patient mortality, followed by D-dimer (>3 $\mu \mathrm{g} / \mathrm{ml}$ ) (Ayanian et al., 2020).

\section{Pathophysiology of COVID-19}

In comparison to high pathogenicity for SARS-CoV or MERS$\mathrm{CoV}$, the pathophysiology of SARS-CoV-2 has not been completely understood. In SARS patients, elevated amounts of pro-inflammatory cytokines (eg, IL1B, IL6, IL12, IFN $\gamma$, IP10, and $\mathrm{MCP} 1)$ are present in serum and is associated with pulmonary inflammation and extensive lung damage (Wong et al., 2004). In MERS-CoV infection, increased concentrations of proinflammatory cytokines (IFN $\gamma, \mathrm{TNF} \alpha$, IL15, and IL17) were reported (Mahallawi et al., 2018). Studies showed that patients infected with COVID-19 also had high amounts of IL1B, IFN $\gamma$, IP10, and MCP1, probably leading to activate T-helper-1 (Th1) cell responses. Also, those patients had higher concentrations of GCSF, IP10, MCP1, MIP1A, and TNF $\alpha$, need not to be admitted to ICU as disease severity is associated with the cytokine storm. Here it differs from SARS-CoV infection as the increased secretion of T-helper-2 (Th2) cytokines (eg, IL4 and IL10) leads to suppressed inflammation in 2019-nCoV infection. To understand the disease autopsy or biopsy are key factors (Huang et al., 2020). The course of infection to susceptible host cells is divided mainly into three phases (Lin et al., 2020).

\subsection{Asymptomatic Phase or Yellow Group}

As the virus enters through nasal, oral, or conjunctiva route and binds to host target epithelial cells ACE2 receptor by its spike (S) protein, following clathrin-mediated endocytosis and leads to further propagation via host machinery, hence when the viral load reaches at a high level, it induces the symptoms (European Medicines Agency, 2020). Also includes promoted virus entry into host cells by expression of two mucosa-specific serine proteases. The TMPRSS2 facilitates SARS-CoV-2 spike fusogenic activity.

\subsection{Symptomatic Phase or Orange Group}

As virus propagates and moves down the respiratory tract leukocyte produces interleukins (ILs). Particularly IL-6 induces "Cytokines storm" which aggravates the condition (Chang et al., 2020). Probably M2 macrophages of alveoli cause the death of the cell forming debris, encounter the virus attack, help in differentiation of B lymphocyte and possibly induce the cytokines that play role in temperature regulation, resulting into fever. Studies implicated that the cytokines generates systemic inflammatory response syndrome (SIRS) characterized by fever and multiple end-organ dysfunction of the host. In a study, decreased cytokines storm (IL-6) activity has a positive recovery sign among patients admitted in ICU with severe pneumonia and fibrosis. Hence, tocilizumab a monoclonal antibody, that blocks the IL- 6 would be proved as an important agent in curbing the infection (Wang et al., 2011; Xu et al., 2020b).In India, about 80\% of the infected patients, the disease is either asymptomatic or reported with mild fever and cough. If the gastrointestinal tract is involved then it exhibit diarrhea.

\subsection{Critical Phase Or Red Group}

During this phase, the virus reaches to alveoli and the viral invasion occurs through ACE2 receptors in alveolar type 2 cells, which further propagates and burst out in the host cell and undergo apoptosis leading to cell death. In addition, virus infect adjacent cells, causing the release of pulmonary toxin to destroy other type 2 cells. Damaged type 2 alveolar cells subsequently commence the regeneration pathway of type II cells that are precursor cells for type I cells (Mossel et al., 2007; Rockx et al., 2009).

Pathophysiologically both SARS and COVID-19 cause diffused alveolar damage resulting formation of fibrin-rich hyaline membranes along with few multinucleated giant cells. The abnormal wound healing may lead to more severe scarring, fibrosis, and acute respiratory distress syndrome (ARDS). Recovery depends upon innate and acquired immune response and epithelial cell regeneration (Weinheimer et al., 2012). The elderly population is at high risk to COVID-19, as old age people have a weak immune response and reduced ability to repair their damaged epithelium including lessened mucociliary clearance, and thus the virus easily moves towards the alveoli (Kumar et al., 2011; Dhama et al., 2020b).

\section{Mechanism of Infection and Immunity of SARS-COV-2}

Vaccines are effective tool against pandemics and these are able to protect the high-risk population, against a variety of pathogens (Graham et al., 2013). The individuals those are recovered from SARS-CoV-2 infection might develop a protective immunity (herd immunity), due to triggered immune response (Bao et al., 2020). Presently, it is uncertain that whether previous exposure to pathogen is able to protect against SARS-CoV-2 in the humans, hence, there is not enough information regarding the impact of this infection on host immunity. Moreover, studies reported that the first line of defence mounted at the entry site i.e., expression of type I IFN (IFN-I) and pro-inflammatory cytokines were suppressed by SARS-CoV and MERS-CoV (Prompetchara et al., 2020).

Pathogenic agents, during cell infection may trigger host humoral and cellular immunities required to eliminate the viral infection but it may cause immunopathology i.e., an uncontrolled or insufficient 
immune response and further causes severe damage to patients (Kruse, 2020).

The cellular infection mechanism of SARS-CoV-2 is mediated by the cell surface receptor ACE2 (Petitprez et al., 2020; Malik et al., 2020), studies also revealed that SARS-CoV-2 infects the cell expressing ACE2 receptors, but not cells which are expressing other coronavirus receptors like aminopeptidase $\mathrm{N}$ and dipeptidyl peptidase 4 (DPP4) (Zhou et al., 2020a; Hoffmann et al., 2020). SARS-CoV-2 mostly infects the respiratory and gastrointestinal tracts (Malik et al., 2020; Chen et al., 2020c). Since ACE2 receptors are abundant on human lung epithelia, small intestine, glandular cells of the seminal vesicle, renal proximal tubules, cardiomyocytes, testicular sertoli cells, leydig cells and gallbladder epithelium (Hikmet et al., 2020). In severe cases, the infection might affect the brain also, and present neurological signs including hyposmia, nausea, vomiting, headache, and cerebral damage (Baig et al., 2020). Furthermore, neurological involvement in further justified by an altered sense of smell. In the brain SARS$\mathrm{CoV}-2$ enters through the ACE2 receptor on endothelium or via the cribriform plate.

The surface-exposed $\mathrm{S}$ glycoprotein is the first viral major component (Zhou et al., 2020b), that facilitates viral binding, membrane fusion, and trafficking inside the target cells. The $S$ glycoprotein of the SARS-CoV-2 consists of two subunits S1 and S2. Subunit S1 contains a receptor-binding domain (RBD) that facilitate virus-receptor binding, whilst $\mathrm{S} 2$ is involved in the fusogenic activity of virus to the host cell membrane (Cui et al., 2019; Walls et al., 2020). Due to similar RBD genomic, the binding mechanism is same as of SARS-CoV and MERS-CoV infection. Activation of pattern recognition receptors (PRR), is a key step to trigger host innate immunity against these viral intruders, but due to lack of these PRR on double membranes of virusevade from host immune responses ( $\mathrm{Li}$ et al., 2020a). According to reports, in critically ill COVID-19 patients, upregulated levels of the cytokine IL-6 in blood has direct correlation with SARS-CoV-2 viral load (Walls et al., 2020). Antigen presentation in peripheral blood of SARS-CoV-2 infected patients is down regulated (Menachery et al., 2018), while upregulated levels of exhausted CD8+ T cells and loss of CD4+ T cell function is reported (Zheng et al., 2020). Moreover, immune insufficiency or misdirection may increase viral replication and cause tissue damage (Li et al., 2020a; Kruse, 2020).

\subsection{Protease inhibitors}

In-vitro entry of the virus is blocked by inhibition or depletion of host proteases, however, an opposite effect on protease treatment is noticed. Proteases like transmembrane protease serine 2 (TMPRSS2) are expressed in human lung cells, its knockout in the cell culture decreases the viral entry (Hoffmann et al., 2020) but exhibit no effect on SARS-CoV-2 infection. Moreover, Camostat and Nefamostat, the TMPRSS2 inhibitors play a role in cell entry mechanism of COVID-19.

\section{Prevention}

Up to present, although many of the drugs are under clinical trials throughout the globe still there are no approved treatments against this virus is available to hospitals, so prevention is crucial. Prolonged incubation period, infection in the conjunctival mucosal surface, asymptomatic transmission, longer illness duration and conveyance post clinical recovery, etc. make prevention difficult (Jin et al., 2020). Persons with close contacts and possible exposure to COVID-19 infected patients should be advised for 14days of self-isolation, starting from the last day of contact. Contact surveillance should be carried out for exposed contact, suspected or confirmed patients (Kim et al., 2015). Once any symptoms of COVID-19 infection are displayed, immediately need to be reported for medical attention (World Health Organization. Home care for patients with suspected novel coronavirus 2020). Home isolation is recommended to suspected cases with mild illness with proper ventilation for fresh air and light is advised by doctors. In addition, wearing a simple mask, appropriate coughing etiquette, and hand hygiene is advised. The rooms and surfaces should be disinfected regularly using ordinary bleach solution $(5 \%)$ or preferably with sodium hypochlorite (1\%). It is advisable for the patient to maintain proper distancing rule especially from elderly people with impaired immune response, pregnant women and persons with co-morbidities within the household (Guidelines for home quarantine, MoHFW 2020). During the period of home isolation, regular follow-up of patient's health should be taken through telephonically or other possible means to go through with advancement of symptoms and, if necessary, the specific recommendation in this regard should be provided by health-care workers (World Health Organization, Home care for patients with suspected novel coronavirus, 2020; General Office of National Health Committee (Trial Version 3) 2020; Wang et al., 2020).

The greatest risk in COVID-19 is transmission to health-care workers has been reported throughout the globe. According to a report from World Health Organization, health-care workers represent less than $3 \%$ of the population throughout the globe and around $14 \%$ of them are infected with COVID-19 as reported (Keep health workers safe to keep patients safe: WHO, 2020). In some countries, the proportion is as high as $35 \%$. During the SARS outbreak in $2002,21 \%$ of those infected patients included health-care workers (Chang et al., 2020). Thousands of health-care workers infected with COVID-19 have lost their lives worldwide. The number of deaths is rising quickly. The doctor who initially indicated about the threat of this viral spread has died too with this infection. To prevent further spread of the disease in health-care workers that are providing their services in the frontline, the onset of fever and 
respiratory symptoms should be closely monitored among them before and after their exposure to 2019-nCoV for identification of asymptomatic infections. Health-care workers should be provided with N95 respirators and protective suits and goggles. Proper training and precautionary measures are required to undertake while undergoing the aerosol-generating procedures including intubation, suction and tracheostomies (Jin et al., 2020).

People should be awakened about the mode of spread of the infection and should be instructed to avoid crowded areas and to wear masks in public. The use of public transport and nonessential travel to places reported with the on-going transmission must be avoided. International visitors should take routine screening and precautions when entering and leaving the affected areas. People need to train about proper coughing etiquettes and hand hygiene frequently every 15-20 min. Suspected or confirmed cases should be reported soon and be monitored and diagnosed in isolated wards of the hospital. The professional health practitioners should make recommendations based on the patient's clinical features. Different suspected and clinical symptoms along with precautionary measures advised by WHO and MoHFW, India respectively has been depicted in Figure 4. In India, patients can be discharged from isolation based on the patient's clinical severity and the discharge policy framed by the Ministry of Health and Family Welfare (MoHFW). The discharge policy is mentioned under discharge standards in the treatment section (Revised Discharge Policy for COVID-19: MoHFW, 2020).

\section{Treatment}

The global fatality count in million units is enough evidence that the world is underprepared to effectively restrain the

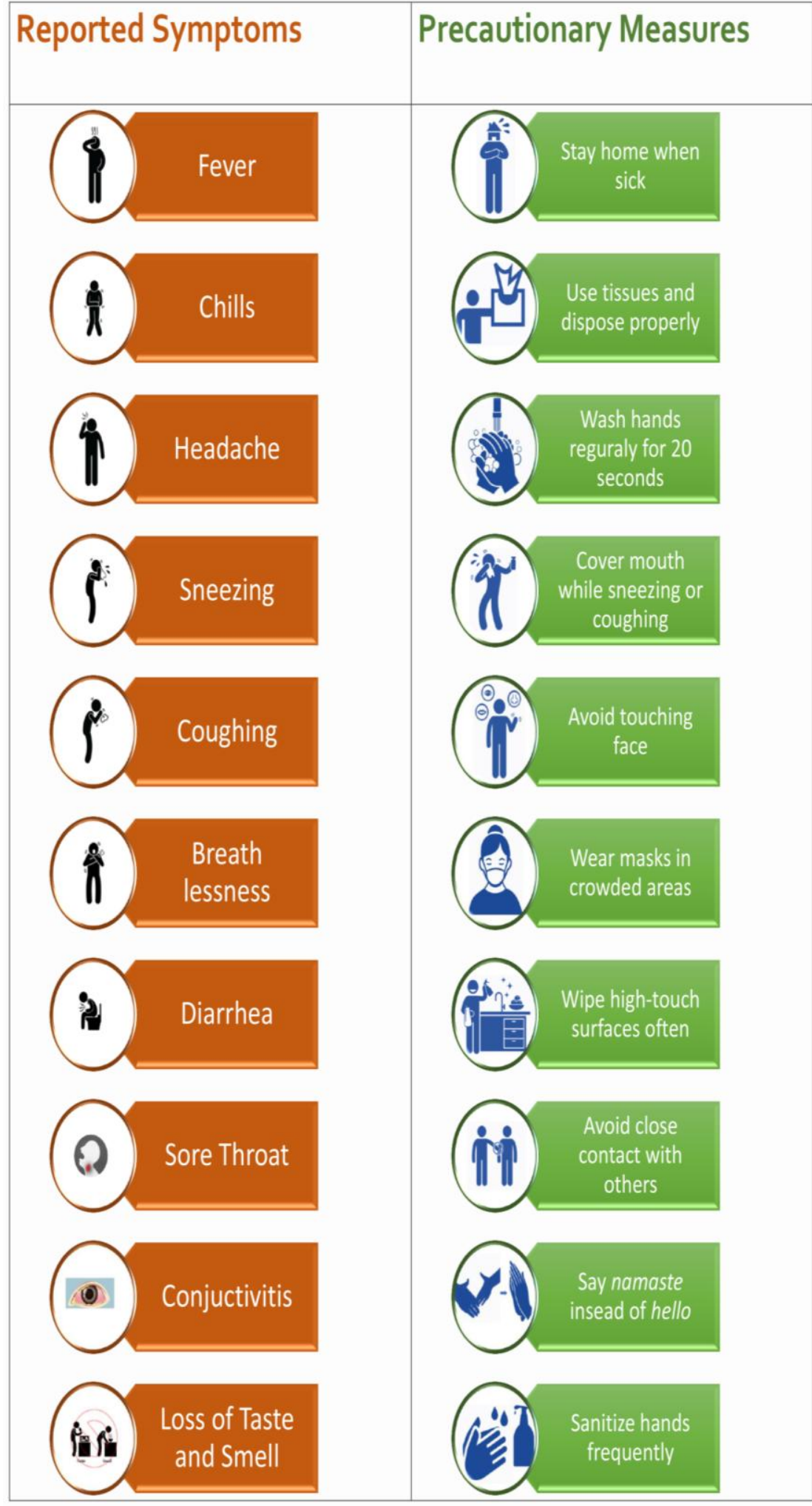

Figure 4 Different suspected and clinical symptoms along with precautionary measures. [WHO, https://www.who.int/emergencies/diseases/novel-coronavirus-2019/advice-for-public ]

Journal of Experimental Biology and Agricultural Sciences http://www.jebas.org 
COVID-19 outbreak despite two former outbreaks of coronavirus infections causing the SARS and MERS. Such newly emerging infectious diseases resulting from RNA viruses are subjected to mutation and genetic recombination. Apart from that cross-species transmission will continue to cause health threats globally in the future. The pandemic caused by SARS-CoV-2 presents an unprecedented challenge to identify effective drugs for prevention and treatment. Up to present, there is no evidence from randomized clinical trials (RCT) to support specific drugs for COVID-19 in suspected or confirmed cases. However, hundreds of active clinical treatment trials are underway. Hence, the first step is to ensure adequate isolation in order to prevent further transmission. The usual principles are maintaining hydration, nutrition and controlling clinical symptoms like fever, cough, headache, etc. through supportive medication. Among patients with the hypoxic condition, provision of oxygen through nasal prongs, face mask, high flow nasal cannula (HFNC), or non-invasive ventilation (NIV) is practiced while in few cases invasive mechanical ventilation is required (Singhal et al., 2020; Jin et al.,2020; Sanders et al., 2020).

\subsection{Selected Repurposed and Investigational Drugs}

Various agents with inconsistent efficacy that previously used to treat SARS and MERS outbreaks are potential candidates to treat COVID-19. Although, a meta-analysis of SARS and MERS treatment studies has not found significant benefit of any specific regimen (Morra et al., 1977; Stockman et al., 2006).

\subsubsection{Lopinavir/Ritonavir and Other Antiretrovirals}

At the time of SARS and MERS, the antiviral drugs such as ribavirin, lopinavir-ritonavir have been used in treatment regimen. When SARS patients were treated with a combination of lopinavirritonavir with ribavirin, they exhibited certain benefits such as reducing the incidence of ARDS or mortality as compared to those given ribavirin alone (Chan et al., 2003; Chu et al., 2004; Lai, 2005; Brigitte et al., 2015; Chen et al., 2020,). The lopinavir-ritonavir's drug effectiveness mainly reported in its early stage (initial 7-10 days), for reducing patient mortality (Jiang et al., 2020).

\subsubsection{Chloroquine and Hydroxychloroquine}

Chloroquine and hydroxychloroquine are with a long-standing history in the treatment of malaria, chronic inflammatory diseases including systemic lupus erythematosus (SLE), and rheumatoid arthritis (Bao et al., 2020). These agents block viral entry into cells by inhibiting host receptors, ACE2 glycosylation and have immunomodulatory effects through attenuation of cytokine production and inhibition of autophagy in host cells (Zhou et al., 2020b; Devaux et al., 2020). Limitations like intolerance of the medications coupled with concerns of additive cardiotoxicity do not support the adoption of this regimen without additional studies.

\subsubsection{Ribavirin}

Ribavirin, a guanine analog demonstrated an inhibitory effect on viral RNA-dependent RNA polymerase (RdRp), thus, reported for COVID-19 treatment. However, its activity against other nCoVs like SARS-CoV was found limited and required a high dose to inhibit viral replication. A case study done previously, has reported its adverse effects including hematologic and liver toxicity due to high concentrations of ribavirin (Stockman et al., 2006). A similar limitation of the drug was seen in the MERS treatment, where approximately $40 \%$ of patients administered with ribavirin plus interferon required blood transfusions (Arabi et al.,2015).

\subsubsection{Other Antivirals}

Oseltamivir, a neuraminidase inhibitor approved for the treatment of influenza, had been initially used in China as outbreak of the pandemic occurred during peak influenza season till the discovery of SARS-CoV-2 as the cause of COVID-19 (Wang \& Lin, 2020). However, this agent has no proposed therapeutic intervention in the treatment of COVID-19 (ClinicalTrials.gov. 2020). Umifenovir /Arbidol is approved treatment in Russia and China for influenza (Khamitov et al., 2008), is gaining interest in China for treating COVID-19 due to its unique antiviral property targeting the protein-receptor (S protein/ACE2) interaction and inhibiting viral envelope membrane fusion (Kadam \& Wilson, 2017).

\subsubsection{Remdesivir}

Remdesivir (formally known GS-5734) is a nucleoside analog, discovered with potent in vitro activity against several $\mathrm{nCoVs}$ such as Coronaviridae (such as SARS-CoV, MERS-CoV, and strains of bat coronaviruses) and Flaviviridae (such as Ebola virus). Up to present, remdesivir is a promising agent for COVID-19 treatment due to its broad-spectrum antiviral effects (acts as an RdRp inhibitor, targeting the viral genome replication process). Currently available in-vitro and in-vivo studies on remdesivir (GS-441524) have demonstrated largely favorable findings. Although remdesivir is a broad-spectrum antiviral, their efficacies against other families of viruses are yet to be elucidated (Amirian \& Levy, 2020).

\subsubsection{Favipiravir}

Favipiravir (formally known as T-705) is a prodrug that also has demonstrated an inhibitory effect on viral RdRp, halting viral replication in influenza and Ebola. However, it is used for therapy of SARS-CoV-2 due to its broad-spectrum antiviral effects (Furuta et al., 2017). A higher dose compared to that of Ebola is used in the treatment of SARS-CoV-2 due to the lower favipiravir $\mathrm{EC}_{50}$ values (loading dose- $2400 \mathrm{mg}$ to $3000 \mathrm{mg}$ every 12 hours $\times$ 2 doses; maintenance dose- $1200 \mathrm{mg}$ to $1800 \mathrm{mg}$ every 12 hours) (Mentré et al., 2015; Sissoko et al., 2016). Up to date, a few 
clinical experiences supporting the use of favipiravir for COVID19 has been reported.

\subsubsection{Corticosteroids}

The corticosteroids are used in order to suppress the host inflammatory responses in the lungs, which may cause acute lung injury and ARDS, and thus, leading to a serious health threat. Even though the role of corticosteroids is unproven in COVID-19 treatment, Chinese guidelines recommend usage of low-to-moderate dose of corticosteroids to prevent COVID-19 ARDS (Russell et al., 2020; Zhao et al., 2020). Methylprednisolone has been found effective in improving clinical symptoms of the patients with SARS and can be used for patients infected with COVID-19 to reduce the degree of disease progression where the total daily dose should not exceed $2 \mathrm{mg} / \mathrm{kg}$. The use of corticosteroids cannot shorten the length of hospital stay for severe ARDS and is yet controversial.

\subsection{Convalescent Plasma Therapy}

Recently, convalescent plasma therapy came into clinical treatment practice that incorporates the use of blood from people who have recovered after getting the infection to help others recover. The U.S. Food and Drug Administration (FDA) has allowed its use during the pandemic as there is no worldwide-approved treatment for COVID-19. Blood of people who have recovered from COVID-19 is processed, leaving behind plasma and antibodies that can be given to the patient of COVID-19 to boost their immunity. However, this therapy has some risk of getting infections such as allergic reactions, HIV, hepatitis B, and C, etc. if donated blood not properly tested (Convalescent plasma therapy: Mayo Clinic, 2020).

\subsection{RNAi Therapy}

RNAi mechanism has been employed to develop front-line therapies by silencing desired genes based on blockage and degradation of corresponding mRNAs by using short interfering RNA (siRNA; 19-27 nucleotide long doublestranded RNAs) and short hairpin RNA (shRNA) molecules. For silencing, effective target selection is essential for its efficacy. RNAi against COVID-19 disease can potentially be directed against targets such as essential viral proteins ( $\mathrm{S}-, \mathrm{N}-$ $\mathrm{M}$-, and E-proteins) and host factors involved in cellular entry and trafficking of the virus (autophagy protein like LC3 and APG5) (Prentice et al., 2004). The physiological goal of the RNAi mechanism is to regulate protein synthesis events. Silencing siRNAs against S-proteins reported most effective in PCR analysis with $85-90 \%$ reduction in viral load (Wu et al., 2005). The rapid transformation in works of literature on
SARS-Co-2 makes it difficult to predict future developments on the use of RNAi agents for COVID-19 disease (Uludag et al., 2020).

\subsection{Discharge Standards}

In India, the discharge policy according to the Ministry of Health and Family Welfare (MoHFW) is categorized based on the patient's clinical severity. For mild/very mild/pre-symptomatic cases, discharge order can be given after 10 days of symptom onset if no fever for atleast 3 days is reported. There is no need for molecular testing prior to discharge. For moderate cases, patients whose symptoms resolve within 3 days such patients will be discharged after 10 days if no fever, breathlessness and oxygen requirement are reported. In addition to moderate cases, patients whose symptoms do not resolve within 3 days, and demand for oxygen continue such patients will be discharged only after the resolution of clinical symptoms. For severe cases including immunocompromised patients discharge criteria are based on clinical recovery and molecular test report after the resolution of symptoms (Revised Discharge Policy for COVID-19: MoHFW, 2020)

In India, AYUSH, MoHFW advisory proposed the daily practice of Yogasana and meditation for at least 30 minutes. For boosting immunity, drinking warm water throughout the day, Chyavanprash, Herbal Tea, and Golden Milk (Haldi milk) are strongly recommended (Ministry of AYUSH, 2020). In addition, the use of traditional Chinese herbs is recommended in the Chinese guidelines (Jin et al., 2020). Figure 5 represents different immunity-boosting advisory for self-care during the COVID-19 crisis

\section{Conclusion}

This novel virus outbreak has posed major challenges to health systems as well as global economy worldwide. Southern China has been the epicenter of many epidemics of 'flu' in the past as well as present pandemic. The outbreak epicenter Wuhan wet market represents the fact that its people, pigs, domestic fowl, bats, and other natural hosts that live close together, increases the likelihood of viral strains genetic recombination to form a new variant that could be pathogenic to the human race. Novel infectious diseases resulting from RNA viruses are subject to get mutation, genetic recombination, as well as cross-species transmission, which may pose severe health threats in the future. As the pandemic continues, a concerted effort to develop effective drugs and vaccines against emerging novel infectious diseases along with early diagnosis methods to identify risk factors may reduce massive impacts on human life and worldwide healthcare systems. 


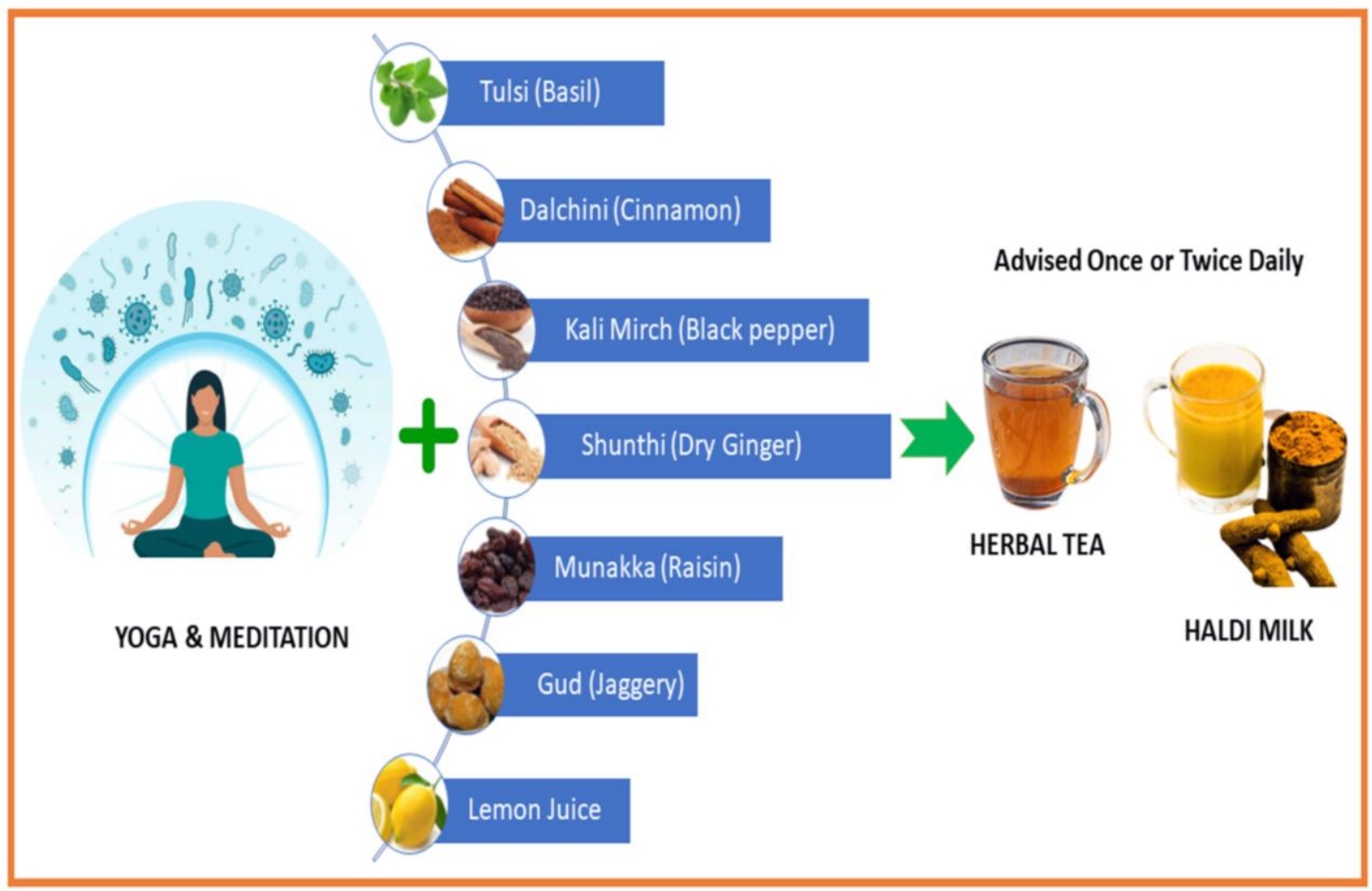

Figure 5 Immunity boosting measures for self-care during COVID-19 crisis. [Guidelines of Ministry of AYUSH, Government of India https://www.mohfw.gov.in/pdf/ImmunityBoostingAYUSHAdvisory.pdf]

\section{Conflict Of Interest}

Authors would hereby like to declare that there is no conflict of interests that could possibly arise.

\section{References}

Ai T, Yang Z, Hou H, Zhan C, Chen C, Lv W, Tao Q, Sun Z, Xia L (2020) Correlation of Chest CT and RT-PCR Testing Coronavirus Disease 2019 (COVID-19) in China: A Report of 1014 Cases. Radiology 296:E32-E40. doi: 10.1148/radiol.2020200642..

Amirian ES, Levy JK (2020) Current knowledge about the antivirals remdesivir (GS-5734) and GS-441524 as therapeutic options for coronaviruses. One Health 9:100128. doi:10.1016/j.onehlt.2020.100128.

Arabi YM, Shalhoub S, Mandourah Y, Al-Hameed F, Al-Omari A, Al Qasim E, Jose J, Alraddadi B, Almotairi A, Al Khatib K, Abdulmomen A, Qushmaq I, Sindi AA, Mady A, Solaiman O, Al-Raddadi R, Maghrabi K, Ragab A, Al Mekhlafi GA, Balkhy HH, Al Harthy A, Kharaba A, Gramish JA, Al-Aithan AM, Al-Dawood A, Merson L,
Hayden FG, Fowler R (2015) Ribavirin and Interferon Therapy for Critically Ill Patients With Middle East Respiratory Syndrome: A Multicenter Observational Study. Clinical Infectious Diseases 70:18371844. doi: 10.1093/cid/ciz544.

Ayanian S, Reyes J, Lynn L, Teufel K (2020) The association between biomarkers and clinical outcomes in novel coronavirus pneumonia in a US cohort. Biomarkers in Medicine 14(22): 10911097. doi:10.2217/bmm-2020-0309.

Baez-Santos YM, St. John SE, Mesecar AD (2015) The SARScoronavirus papain-like protease: structure, function and inhibition by designed antiviral compounds. Antiviral Research 115:21-38. doi: 10.1016/j.antiviral.2014.12.015.

Bai Y, Yao L, Wei T, Tian F, Jin DY, Chen L, Wang M (2020) Presumed Asymptomatic Carrier Transmission of COVID-19. JAMA 323:1406-1407. doi: 10.1001/jama.2020.2565.

Baig AM, Khaleeq A, Ali U, Syeda H (2020) Evidence of the COVID-19 Virus Targeting the CNS: Tissue Distribution, HostVirus Interaction, and Proposed Neurotropic Mechanisms. ACS 
Chemical Neuroscience 11:995-998.

10.1021/acschemneuro.0c00122.

Bao L, Deng W, Gao H, Xiao C, Liu J, Xue J, Lv Q, Liu J, Yu P, Xu Y, Qi F, Qu Y, Li F, Xiang Z, Yu H, Gong S, Liu M, Wang G, Wang S, Song Z, Zhao W, Han Y, Zhao L, Liu X, Wei Q, Qin C (2020) Reinfection could not occur in SARS-CoV-2 infected rhesus macaques. bioRxiv 2020.03.13.990226; doi: https://doi.org/10.1101/2020.03.13.990226

Barnkob MB, Pottegård A, Støvring H, Haunstrup TM, Homburg K, Larsen R, Hansen MB, Titlestad K, Aagaard B, Møller BK, Barington T (2020) Reduced prevalence of SARS-CoV-2 infection in ABO blood group O. Blood Advances 4(20): 4990-4993. doi: 10.1182/bloodadvances.2020002657.

Brigitte M, Arti B, Stephan A, Judith A, Bruno R, Christoph W (2015) MERS-COV disease associated ARDS -a case report. Critical Care Medicine 43:308.

Chan KS, Lai ST, Chu CM, Tsui E, Tam CY, Wong MM, Tse MW, Que TL, Peiris JS, Sung J, Wong VC, Yuen KY (2003) Treatment of severe acute respiratory syndrome with lopinavir/ritonavir: a multicentre retrospective matched cohort study. Hong Kong Medical Journal 9:399-406.

Chang D, Xu H, Rebaza A, Sharma L, Dela Cruz CS (2020) Protecting health-care workers from subclinical coronavirus infection. The Lancet Respiratory medicine 8:e13. https://doi.org/10.1016/S2213-2600(20)30066-7.

Chan-Yeung M, Xu RH (2003) SARS: epidemiology. Respirology 8:S9-S14. doi:10.1046/j.1440-1843.2003.00518.x

Chen H, Guo J, Wang C, Luo F, Yu X, Zhang W, Li J, Zhao D, Xu D, Gong Q, Liao J, Yang H, Hou W, Zhang Y (2020a) Clinical characteristics and intrauterine vertical transmission potential of COVID-19 infection in nine pregnant women: a retrospective review of medical records. The Lancet 395:809-815. doi: 10.1016/S0140-6736(20)30360-3.

Chen N, Zhou M, Dong X, Qu J, Gong F, Han Y, Qiu Y, Wang J, Liu Y, Wei Y, Xia J, Yu T, Zhang X, Zhang L (2020b) Epidemiological and clinical characteristics of 99 cases of 2019 novel coronavirus pneumonia in Wuhan, China: a descriptive study. The Lancet 395:507-513. doi: 10.1016/S01406736(20)30211-7.

Chen WH, Strych U, Hotez PJ, Bottazzi ME (2020c) The SARSCoV-2 Vaccine Pipeline: an Overview. Current Tropical Medicine Reports 3:1-4. doi: 10.1007/s40475-020-00201-6. oi: Cheng ZJ, Shan J (2019) Novel coronavirus: where we are and what we know. Infection 48:155-163. doi: 10.1007/s15010-02001401-y.

Chu CM, Cheng VC, Hung IF, Wong MM, Chan KH, Chan KS, Kao RY, Poon LL, Wong CL, Guan Y, Peiris JS, Yuen KY (2004) Role of lopinavir/ritonavir in the treatment of SARS: initial virological and clinical findings. Thorax 59:252-6. doi: 10.1136/thorax.2003.012658.

ClinicalTrials.gov (2020) Available at https://clinicaltrials.gov/ access on October 02, 2020.

Convalescent plasma therapy: Mayo Clinic (2020) Available at https://www.mayoclinic.org/tests-procedures/convalescent-plasmatherapy/about/pac-20486440 access on October 02, 2020.

Coronavirus Outbreak (2020) Available at https://www.worldometers.info/coronavirus/ Access on October 02,2020

Cui J, Li F, Shi ZL (2019) Origin and evolution of pathogenic coronaviruses. Nature Reviews Microbiology 17:181-192. doi: https://doi.org/10.1038/s41579-018-0118-9.

Devaux CA, Rolain JM, Colson P, Raoult D (2020) New insights on the antiviral effects of chloroquine against coronavirus: what to expect for COVID-19? International Journal of Antimicrobial Agents 55:105938. doi:10.1016/j.jjantimicag.2020.105938.

Dhama K, Khan S, Tiwari R, Sircar S, Bhat S, Malik YS, Singh KP, Chaicumpa W, Katterine D Bonilla-Aldana DK , RodriguezMorales AJ (2020a) Coronavirus Disease 2019-COVID-19. Clinical Microbiology Reviews 33 (4) e00028-20. doi: 10.1128/CMR.00028-20.

Dhama K, Patel SK, Kumar R, Rana J, Yatoo MI, Kumar A, Tiwari R, Dhama J, Natesan S, Singh R, Harapan H (2020b) Geriatric Population During the COVID-19 Pandemic: Problems, Considerations, Exigencies, and Beyond. Frontiers in Public Health 8:562. doi: 10.3389/fpubh.2020.574198.

Dhama K, Patel SK, Pathak M, Yatoo MI, Tiwari R, Malik YS, Singh R, Sah R, Rabaan AA, Bonilla-Aldana DK, RodriguezMorales AJ (2020c) An update on SARS-CoV-2/COVID-19 with particular reference to its clinical pathology, pathogenesis, immunopathology and mitigation strategies. Travel Medicine and Infectious Disease 30:101755. doi: 10.1016/j.tmaid.2020.101755.

Du L, He Y, Zhou Y, Liu S, Zheng BJ, Jiang S (2009) The spike protein of SARS-CoV--a target for vaccine and therapeutic development. Nature Reviews Microbiology 7:226-36. doi: 10.1038/nrmicro2090. 
Ellinghaus D, Karlsen TH (2020) Severe Covid-19 GWAS Group. Genomewide Association Study of Severe Covid-19 with Respiratory Failure. The New England Journal of Medicine 383:1522-1534. doi: 10.1056/NEJMoa2020283.

European Medicines Agency (2020) EMA Gives Advice on the Use of Non-steroidal Anti-inflammatories for COVID-19. Available from: https://www.ema.europa.eu/en/news/emagivesadvice-use-non-steroidal-anti-inflammatories-covid-19. [Last accessed on 2020 Mar 25].

Florindo HF, Kleiner R, Vaskovich-Koubi D, Acúrcio RC Carreira B, Yeini E, GaliaTiram G, Liubomirski Y, Satchi-Fainaro $\mathrm{R}$ (2020) Immune-mediated approaches against COVID-19. Nature Nanotechnology 15:630-645. https://doi.org/10.1038/s41565-0200732-3.

Foy BH, Carlson JCT, Reinertsen E (2020) Association of Red Blood Cell Distribution Width With Mortality Risk in Hospitalized Adults With SARS-CoV-2 Infection. JAMA Netw Open 3(9):e2022058. doi:10.1001/jamanetworkopen.2020.22058.

Furuta Y, Komeno T, Nakamura T (2017) Favipiravir (T-705), a broad spectrum inhibitor of viral RNA polymerase. Proceedings of The Japan Academy Series B: Physical And Biological Sciences 93:449-463. doi:10.2183/pjab.93.027.

General Office of National Health Committee. Office of State Administration of Traditional Chinese Medicine (2020) Notice on the issuance of a programme for the diagnosis and treatment of novel coronavirus (2019-nCoV) infected pneumonia (Trial Version 4). 2020. http://bgs.satcm.gov.cn/zhengcewenjian/2020-0128/12576.html. Accessed 29 Jan 2020.

General Office of National Health Committee. Office of State Administration of Traditional Chinese Medicine (2020) Notice on the issuance of a program for the diagnosis and treatment of novel coronavirus (2019-nCoV) infected pneumonia (Trial Version 3) (2020). Available http://www.nhc.gov.cn/xcs/zhengcwj/202001/f492c9153ea9437bb 587ce2ffcbee1fa.shtml Access on October 02, 2020.

Gerna G, Campanini G, Rovida F, Percivalle E, Sarasini A, Marchi A, Baldanti F (2006) Genetic variability of human coronavirus OC43-, 229E-, and NL63-like strains and their association with lower respiratory tract infections of hospitalized infants and immunocompromised patients. Journal of Medical Virology 78:938-49. doi: 10.1002/jmv.20645.

Graham BS (2013) Advances in antiviral vaccine development. Immunological Reviews 255:230-242. doi:10.1111/imr.12098.
Guidelines for home quarantine (2020) Available at https://www.mohfw.gov.in/pdf/Guidelinesforhomequarantine.pdf Access on October 02, 2020.

Hikmet F, Méar L, Uhlén M, Lindskog C (2020) The protein expression profile of ACE2 in human tissues. bioRxiv 2020.03.31.016048. doi: https://doi.org/10.1101/2020.03.31.016048.

Hoffmann M, Kleine-Weber H, Schroeder S, Krüger N, Herrler T, Erichsen S, Schiergens TS, Herrler G, Wu NH, Nitsche A, Müller MA, Drosten C, Pöhlmann S (2020) SARS-CoV-2 Cell Entry Depends on ACE2 and TMPRSS2 and Is Blocked by a Clinically Proven Protease Inhibitor. Cell 181:271-280.e8. doi: 10.1016/j.cell.2020.02.052.

Huang C, Wang Y, Li X, Ren L, Zhao J, Hu Y, Zhang L, Fan G, Xu J, Gu X, Cheng Z, Yu T, Xia J, Wei Y, Wu W, Xie X, Yin W, Li H, Liu M, Xiao Y, Gao H, Guo L, Xie J, Wang G, Jiang R, Gao Z, Jin Q, Wang J, Cao B (2020) Clinical features of patients infected with 2019 novel coronavirus in Wuhan, China. The Lancet 395:497-506. doi: 10.1016/S0140-6736(20)30183-5.

Jiang H, Deng H, Wang Y, Liu Z, Sun WM (2020) The possibility of using Lopinave/Litonawe (LPV/r) as treatment for novel coronavirus 2019-nCov pneumonia: a quick systematic review based on earlier coronavirus clinical studies. Zhonghua Jizhen Yixue Zazhi 29:182-6.

Jin YH, Cai L, Cheng ZS, Cheng H, Deng T, Fan YP, Fang C, Huang D, Huang LQ, Huang Q, Han Y, Hu B, Hu F, Li BH, Li YR, Liang K, Lin LK, Luo LS, Ma J, Ma LL, Peng ZY, Pan YB, Pan ZY, Ren XQ, Sun HM, Wang Y, Wang YY, Weng H, Wei CJ, Wu DF, Xia J, Xiong Y, Xu HB, Yao XM, Yuan YF, Ye TS, Zhang XC, Zhang YW, Zhang YG, Zhang HM, Zhao Y, Zhao MJ, Zi H, Zeng XT, Wang YY, Wang XH (2020) A rapid advice guideline for the diagnosis and treatment of 2019 novel coronavirus (2019-nCoV) infected pneumonia (standard version). Military Medical Research7:4. doi: 10.1186/s40779-020-0233-6.

Kadam RU, Wilson IA (2017) Structural basis of influenza virus fusion inhibition by the antiviral drug Arbidol. Proceedings of the National Academy of Sciences of the United States of America114:206-214. doi:10.1073/pnas.1617020114.

Kampf G, Todt D, Pfaender S, Steinmann E (2020) Persistence of coronaviruses on inanimate surfaces and their inactivation with biocidal agents. Journal of Hospital Infection 104(3):246-251. doi: 10.1016/j.jhin.2020.01.022.

Keep health workers safe to keep patients safe: Available at WHO (2020). https://www.who.int/news-room/detail/17-09-2020-keep- 
health-workers-safe-to-keep-patients-safe-who Access on October 02, 2020.

Khamitov RA, Loginova SI, Shchukina VN, Borisevich SV, Maksimov VA, Shuster AM (2008) Antiviral activity of arbidol and its derivatives against the pathogen of severe acute respiratory syndrome in the cell cultures. Voprosy Virusologii 53:9-13.

Khandia R, Singhal S, Kumar U, Ansari A, Tiwari R, Dhama K, Das J, Munjal A, Singh RK (2019) Analysis of Nipah Virus Codon Usage and Adaptation to Hosts. Frontiers in Microbiology 10:886. doi: 10.3389/fmicb.2019.00886.

Kim JY, Song JY, Yoon YK, Choi SH, Song YG, Kim SR, Son HJ, Jeong SY, Choi JH, Kim KM, Yoon HJ, Choi JY, Kim TH, Choi YH, Kim HB, Yoon JH, Lee J, Eom JS, Lee SO, Oh WS, Choi JH, Yoo JH, Kim WJ, Cheong HJ (2015) Middle East Respiratory Syndrome Infection Control and Prevention Guideline for Healthcare Facilities. Infection \& Chemotherapy 47:278-302. doi: 10.3947/ic.2015.47.4.278.

Kruse RL (2020) Therapeutic strategies in an outbreak scenario to treat the novel coronavirus originating in Wuhan, China. F1000Research 9:72. doi: 10.12688/f1000research.22211.2. PMID: 32117569; PMCID: PMC7029759.

Kumar PA, Hu Y, Yamamoto Y, Hoe NB, Wei TS, Mu D, Sun Y, Joo LS, Dagher R, Zielonka EM, Wang de Y, Lim B, Chow VT, Crum CP, Xian W, McKeon F (2011) Distal airway stem cells yield alveoli in vitro and during lung regeneration following H1N1 influenza infection. Cell 147:525-38. doi: 10.1016/j.cell.2011.10.001.

Lagier JC, Colson P, TissotDupont H, Salomon J, Doudier B, Aubry C, Gouriet F, Baron S, Dudouet P, Flores R, Ailhaud L, Gautret P, Parola P, La Scola B, Raoult D, Brouqui P (2020) Testing the repatriated for SARS-Cov2: Should laboratory-based quarantine replace traditional quarantine?. Travel Medicine and Infectious Disease 34:101624. doi: 10.1016/j.tmaid.2020.101624.

Lai ST (2005) Treatment of severe acute respiratory syndrome. European Journal of Clinical Microbiology \& Infectious Diseases 24:583-91. doi: 10.1007/s10096-005-0004-z.

Lauer SA, Grantz KH, Bi Q, Jones FK, Zheng Q, Meredith HR, Azman AS, Reich NG, Lessler J (2020) The Incubation Period of Coronavirus Disease 2019 (COVID-19) From Publicly Reported Confirmed Cases: Estimation and Application. Annals of Internal Medicine 172:577-582. doi: 10.7326/M20-0504.

Li G, Fan Y, Lai Y, Han T, Li Z, Zhou P, Pan P, Wang W, Hu D, Liu X, Zhang Q, Wu J (2020a) Coronavirus infections and immune responses. Journal of Medical Virology 92:424-432. doi: 10.1002/jmv.25685.

Li Q, Guan X, Wu P, Wang X, Zhou L, Tong Y, Ren R, Leung KSM, Lau EHY, Wong JY, Xing X, Xiang N, Wu Y, Li C, Chen Q, Li D, Liu T, Zhao J, Liu M, Tu W, Chen C, Jin L, Yang R, Wang Q, Zhou S, Wang R, Liu H, Luo Y, Liu Y, Shao G, Li H, Tao Z, Yang Y, Deng Z, Liu B, Ma Z, Zhang Y, Shi G, Lam TTY, Wu JT, Gao GF, Cowling BJ, Yang B, Leung GM, Feng Z (2020b) Early Transmission Dynamics in Wuhan, China, of Novel Coronavirus-Infected Pneumonia. The New England Journal of Medicine 382:1199-1207. doi: 10.1056/NEJMoa2001316.

Lin L, Lu L, Cao W, Li T (2020) Hypothesis for potential pathogenesis of SARS-CoV-2 infection-a review of immune changes in patients with viral pneumonia. Emerging Microbes \& Infections9:727-732. doi:10.1080/22221751.2020.1746199.

Lippi G, Simundic AM, Plebani M (2020) Potential preanalytical and analytical vulnerabilities in the laboratory diagnosis of coronavirus disease 2019 (COVID-19). Clinical Chemistry and Laboratory Medicine 58:1070-1076. doi: 10.1515/cclm-20200285. PMID: 32172228.

Liu C, Zhou Q, Li Y, Garner LV, Watkins SP, Carter LJ, Smoot J, Gregg AC, Daniels AD, Jervey S, Albaiu D (2020a) Research and Development on Therapeutic Agents and Vaccines for COVID-19 and Related Human Coronavirus Diseases. ACS Central Science. 6:315-331. doi: 10.1021/acscentsci.0c00272.

Liu R, Yi S, Zhang J, Lv Z, Zhu C, Zhang Y (2020b) Viral Load Dynamics in Sputum and Nasopharyngeal Swab in Patients with COVID-19. Journal of Dental Research 99:1239-1244. doi: $10.1177 / 0022034520946251$.

Ljungström L, Pernestig AK, Jacobsson G, Andersson R, Usener B, Tilevik D (2017) Diagnostic accuracy of procalcitonin, neutrophil-lymphocyte count ratio, C-reactive protein, and lactate in patients with suspected bacterial sepsis. PLoS One 12:e0181704. doi:10.1371/journal.pone.0181704.

Mahallawi WH, Khabour OF, Zhang Q, Makhdoum HM, Suliman BA (2018) MERS-CoV infection in humans is associated with a pro-inflammatory Th1 and Th17 cytokine profile. Cytokine 104:813. doi: 10.1016/j.cyto.2018.01.025.

Malik YS, Sircar S, Bhat S, Sharun K, Dhama K, Dadar M, Tiwari R, Chaicumpa W (2020) Emerging novel coronavirus (2019nCoV)-current scenario, evolutionary perspective based on genome analysis and recent developments. Veterinary Quarterly 40:68-76. doi: 10.1080/01652176.2020.1727993. 
Menachery VD, Schäfer A, Burnum-Johnson KE, Mitchell HD, Eisfeld AJ, Walters KB, Nicora CD, Purvine SO, Casey CP, Monroe ME, Weitz KK, Stratton KG, Webb-Robertson BM, Gralinski LE, Metz TO, Smith RD, Waters KM, Sims AC, Kawaoka Y, Baric RS (2018) MERS-CoV and H5N1 influenza virus antagonize antigen presentation by altering the epigenetic landscape. Proceedings of the National Academy of Sciences of the United States of America115:E1012-E1021. doi: 10.1073/pnas. 1706928115 .

Mentré F, Taburet AM, Guedj J, Anglaret X, Keïta S, de Lamballerie X, Malvy D (2015) Dose regimen of favipiravir for Ebola virus disease. The Lancet Infectious Diseases15:150-1. doi: 10.1016/S1473-3099(14)71047-3. Epub 2014 Nov 28. PMID: 25435054.

Middle East Respiratory Syndrome Coronavirus (2020) Available at: https://www.who.int/emergencies/mers-cov/en/ Access on October 02, 2020.

Ministry of AYUSH (2020) Ayurveda's immunity boosting measures for selfcare during COVID 19 crisis. Available at https://www.mohfw.gov.in/pdf/ImmunityBoostingAYUSHAdvisor y.pdf Access on October 02, 2020.

Morra ME, Van Thanh L, Kamel MG, Ghazy AA, Altibi AMA, Dat LM, Thy TNX, Vuong NL, Mostafa MR, Ahmed SI, Elabd SS, Fathima S, Le Huy Vu T, Omrani AS, Memish ZA, Hirayama K, Huy NT (1977) Clinical outcomes of current medical approaches for Middle East respiratory syndrome: A systematic review and meta-analysis. Reviews in Medical Virology 28:e1977. doi: 10.1002/rmv.1977.

Morse JS, Lalonde T, Xu S, Liu WR (2020) Learning from the Past: Possible Urgent Prevention and Treatment Options for Severe Acute Respiratory Infections Caused by 2019-nCoV. Chembiochem 21:730-738. doi: 10.1002/cbic.202000047.

Mossel EC, Wang J, Jeffers S, Edeen KE, Wang S, Cosgrove GP, Funk CJ, Manzer R, Miura TA, Pearson LD, Holmes KV, Mason RJ (2007) SARS-CoV replicates in primary human alveolar type II cell cultures but not in type I-like cells. Virology 372:127-35. doi: 10.1016/j.virol.2007.09.045.

Perlman S (2020) Another decade, another coronavirus. The New England Journal of Medicine 382:760-762 https://doi.org/10.1056/NEJMe2001126.

Petitprez F, de Reyniès A, Keung EZ, Chen TW, Sun CM, Calderaro J, Jeng YM, Hsiao LP, Lacroix L, Bougoüin A, Moreira M, Lacroix G, Natario I, Adam J, Lucchesi C, Laizet YH, Toulmonde M, Burgess MA, Bolejack V, Reinke D, Wani KM, Wang WL, Lazar AJ, Roland CL, Wargo JA, Italiano A, Sautès-
Fridman C, Tawbi HA, Fridman WH (2020) B cells are associated with survival and immunotherapy response in sarcoma. Nature 577:556-560. doi: 10.1038/s41586-019-1906-8.

Prentice E, Jerome WG, Yoshimori T, Mizushima N, Denison MR (2004) Coronavirus replication complex formation utilizes components of cellular autophagy. Journal of Biological Chemistry 279:10136-10141. doi: 10.1074/jbc.M306124200.

Prompetchara E, Ketloy C, Palaga T (2020) Immune responses in COVID-19 and potential vaccines: Lessons learned from SARS and MERS epidemic. Asian Pacific Journal of Allergy and Immunology 38:1-9. doi: 10.12932/AP-200220-0772. PMID: 32105090 .

Revised Discharge Policy for COVID-19: MoHFW (2020) Available at https://www.mohfw.gov.in/pdf/ReviseddischargePolicyforCOVID 19.pdf Access on October 02, 2020.

Richman DD, Whitley RJ, Hayden FG (2016) Clinical virology. 4th edn. ASM Press, Washington2016.

Rockx B, Baas T, Zornetzer GA, Haagmans B, Sheahan T, Frieman M, Dyer MD, Teal TH, Proll S, van den Brand J, Baric R, Katze MG (2009) Early upregulation of acute respiratory distress syndrome-associated cytokines promotes lethal disease in an agedmouse model of severe acute respiratory syndrome coronavirus infection. Journal of Virology 83:7062-74. doi: 10.1128/JVI.00127-09.

Rothe C, Schunk M, Sothmann P, Bretzel G, Froeschl G, Wallrauch C, Zimmer T, Thiel V, Janke C, Guggemos W, Seilmaier M, Drosten C, Vollmar P, Zwirglmaier K, Zange S, Wölfel R, Hoelscher M (2020) Transmission of 2019-nCoV Infection from an Asymptomatic Contact in Germany. The New England Journal of Medicine 382:970-971. doi: 10.1056/NEJMc2001468.

Russell CD, Millar JE, Baillie J (2020) Clinical evidence does not support corticosteroid treatment for 2019-nCoV lung injury. The Lancet 395:473-475. doi: 10.1016/S0140-6736(20)30317-2.

Sanders JM, Monogue ML, Jodlowski TZ, Cutrell JB (2020) Pharmacologic Treatments for Coronavirus Disease 2019 (COVID-19): A Review. JAMA 323:1824-1836. doi:10.1001/jama.2020.6019.

Singhal T (2020) A Review of Coronavirus Disease-2019 (COVID-19). The Indian Journal of Pediatrics 87:281-286. doi:10.1007/s12098-020-03263-6. 
Sissoko D, Laouenan C, Folkesson E, M'Lebing AB, Beavogui AH, Baize S, Camara AM, Maes P, Shepherd S, Danel C, Carazo S, Conde MN, Gala JL, Colin G, Savini H, Bore JA, Le Marcis F, Koundouno FR, Petitjean F, Lamah MC, Diederich S, Tounkara A, Poelart G, Berbain E, Dindart JM, Duraffour S, Lefevre A, Leno T, Peyrouset O, Irenge L, Bangoura N, Palich R, Hinzmann J, Kraus A, Barry TS, Berette S, Bongono A, Camara MS, Chanfreau Munoz V, Doumbouya L, SouleyHarouna, Kighoma PM, Koundouno FR, RénéLolamou, Loua CM, Massala V, Moumouni K, Provost C, Samake N, Sekou C, Soumah A, Arnould I, Komano MS, Gustin L, Berutto C, Camara D, Camara FS, Colpaert J, Delamou L, Jansson L, Kourouma E, Loua M, Malme K, Manfrin E, Maomou A, Milinouno A, Ombelet S, Sidiboun AY, Verreckt I, Yombouno P, Bocquin A, Carbonnelle C, Carmoi T, Frange P, Mely S, Nguyen VK, Pannetier D, Taburet AM, Treluyer JM, Kolie J, Moh R, Gonzalez MC, Kuisma E, Liedigk B, Ngabo D, Rudolf M, Thom R, Kerber R, Gabriel M, Di Caro A, Wölfel R, Badir J, Bentahir M, Deccache Y, Dumont C, Durant JF, El Bakkouri K, GasasiraUwamahoro M, Smits B, Toufik N, Van Cauwenberghe S, Ezzedine K, D'Ortenzio E, Pizarro L, Etienne A, Guedj J, Fizet A, Barte de Sainte Fare E, Murgue B, Tran-Minh T, Rapp C, Piguet P, Poncin M, Draguez B, AllafordDuverger T, Barbe S, Baret G, Defourny I, Carroll M, Raoul H, Augier A, Eholie SP, Yazdanpanah Y, Levy-Marchal C, Antierrens A, Van Herp M, Günther S, de Lamballerie X, Keïta S, Mentre F, Anglaret X, Malvy D (2016) Treatment with Favipiravir for Ebola Virus Disease (the JIKI Trial): A Historically Controlled, Single-Arm Proof-of-Concept Trial in Guinea. PLoS Medicine.13:e1001967. doi: 10.1371/journal.pmed.1001967

Stockman LJ, Bellamy R, Garner P (2006) SARS: systematic review of treatment effects. PLoS Medicine 3:e343. doi 10.1371/journal.pmed.0030343.

Summary of probable SARS cases with onset of illness from 1 November 2002 to 31 July 2003. Geneva: World Health Organization (2004) Available at https://www.who.int/csr/sars/country/ table2004_04_21/ en/ Access on October 02, 2020.

Uludağ H, Parent K, Aliabadi HM, Haddadi A (2020) Prospects for RNAi Therapy of COVID-19. Frontiers in Bioengineering and Biotechnology 8: 916. doi:10.3389/fbioe.2020.00916.

Walls AC, Park YJ, Tortorici MA, Wall A, McGuire AT, Veesler D (2020) Structure, Function, and Antigenicity of the SARS-CoV2 Spike Glycoprotein. Cell 181:281-292.e6. doi: 10.1016/j.cell.2020.02.058.

Wang D, Hu B, Hu C, Zhu F, Liu X, Zhang J, Wang B, Xiang H, Cheng Z, Xiong Y, Zhao Y, Li Y, Wang X, Peng Z (2020) Clinical Characteristics of 138 Hospitalized Patients With 2019 Novel
Coronavirus-Infected Pneumonia in Wuhan, China. JAMA 323:1061-1069. doi: 10.1001/jama.2020.1585.

Wang J, Nikrad MP, Phang T, Gao B, Alford T, Ito Y, Edeen K, Travanty EA, Kosmider B, Hartshorn K, Mason RJ (2011) Innate immune response to influenza A virus in differentiated human alveolar type II cells. American Journal of Respiratory Cell and Molecular Biology 45:582-91. doi: 10.1165/rcmb.2010-0108OC.

Wang Y, Lin LK (2020) An advice guideline recommended by central south hospital for the suspected patients of novel coronavirus (2019-nCoV) infected pneumonia and their close contacts as at home quarantine. 2020. Available at https://mp.weixin.qq.com/s/xFO10WAFB9OUnM7VN92R2w Access on October 02, 2020.

Weinheimer VK, Becher A, Tönnies M, Holland G, Knepper J, Bauer TT, Schneider P, Neudecker J, Rückert JC, Szymanski K, Temmesfeld-Wollbrueck B, Gruber AD, Bannert N, Suttorp N, Hippenstiel S, Wolff T, Hocke AC (2012) Influenza A viruses target type II pneumocytes in the human lung. The Journal of Infectious Diseases206:1685-94. doi: 10.1093/infdis/jis455.

WHO-China joint mission on COVID-19 final report (2020) Available at https://www.who.int/docs/defaultsource/coronaviruse/who-china-joint-mission-on-covid-19final-report.pdf Access on October 02, 2020.

Wong CK, Lam CW, Wu AK, Ip WK, Lee NL, Chan IH, Lit LC, Hui DS, Chan MH, Chung SS, Sung JJ (2004) Plasma inflammatory cytokines and chemokines in severe acute respiratory syndrome. Clinical and Experimental Immunology 136:95-103. doi: 10.1111/j.1365-2249.2004.02415.x.

World Health Organization. Home care for patients with suspected novel coronavirus ( $\mathrm{nCoV}$ ) infection presenting with mild symptoms and management of contacts (2020) Available at https://www.who.int/publications-detail/home-care-forpatients-with-suspected-novel-coronavirus-(ncov)-infectionpresenting-with-mild-symptoms-and-management-of-contacts Access on October 02, 2020.

World Health Organization. Situation reports (2020) Available at: https://www.who.int/emergencies/diseases/novelcoronavirus-2019/situation-reports/ Access on October 02, 2020.

Wrapp D, Wang N, Corbett KS, Goldsmith JA, Hsieh CL, Abiona O, Graham BS, McLellan JS (2020) Cryo-EM structure 
of the 2019-nCoV spike in the prefusion conformation. Science 367:1260-1263. doi: 10.1126/science.abb2507.

Wu CJ, Huang HW, Liu CY, Hong CF, Chan Y L (2005) Inhibition of SARS-CoV replication by siRNA. Antiviral Research 65:45-48. doi: 10.1016/j.antiviral.2004.09.005.

Wu Z, McGoogan JM (2020) Characteristics of and Important Lessons From the Coronavirus Disease 2019 (COVID-19) Outbreak in China: Summary of a Report of 72314 Cases From the Chinese Center for Disease Control and Prevention. JAMA 323(13):1239-1242. doi:10.1001/jama.2020.2648.

Xu XW, Wu XX, Jiang XG, Xu KJ, Ying LJ, Ma CL, Li SB, Wang HY, Zhang S, Gao HN, Sheng JF, Cai HL, Qiu YQ, Li LJ (2020a) Clinical findings in a group of patients infected with the 2019 novel coronavirus (SARS-Cov-2) outside of Wuhan, China: retrospective case series. BMJ 368:m606. doi: 10.1136/bmj.m606.

Xu Z, Shi L, Wang Y, Zhang J, Huang L, Zhang C, Liu S, Zhao P, Liu H, Zhu L, Tai Y, Bai C, Gao T, Song J, Xia P, Dong J, Zhao J, Wang FS (2020b) Pathological findings of COVID-19 associated with acute respiratory distress syndrome. The Lancet Respiratory Medicine 8:420-422. doi: 10.1016/S2213-2600(20)30076-X.

Zeng LK, Tao XW, YuanWH, Wang J, Liu X, Liu ZS (2020) First case of neonate infected with novel coronavirus pneumonia in China. ZhonghuaErKeZaZhi 58:E009. doi: 10.3760/cma.j.issn.0578-1310.2020.0009.

Zhang SF, Tuo JL, Huang XB, Zhu X, Zhang DM, Zhou K, Yuan L, Luo HJ, Zheng BJ, Yuen KY, Li MF, Cao KY, Xu L (2018) Epidemiology characteristics of human coronaviruses in patients with respiratory infection symptoms and phylogenetic analysis of HCoV-OC43 during 2010-2015 in Guangzhou. PLoS One 13:e191789. doi: 10.1371/journal.pone.0191789.

Zhao JP, Hu Y, Du RH, Chen ZS, Jin Y, Zhou M, Zhang J, Qu JM, Cao B (2020) Expert consensus on the use of corticosteroid in patients with 2019-nCoV pneumonia. ZhonghuaJie $\mathrm{He} \mathrm{He} \mathrm{Hu} \mathrm{Xi}$ ZaZhi. 43:E007. doi: 10.3760/cma.j.issn.1001-0939.2020.0007.

Zheng HY, Zhang M, Yang CX, Zhang N, Wang XC, Yang XP, Dong XQ, Zheng YT (2020) Elevated exhaustion levels and reduced functional diversity of $\mathrm{T}$ cells in peripheral blood may predict severe progression in COVID-19 patients. Cellular \& Molecular Immunology 17:541-543. doi: 10.1038/s41423-0200401-3.

Zhou D, Dai SM, Tong Q (2020a) COVID-19: a recommendation to examine the effect of hydroxychloroquine in preventing infection and progression. Journal of Antimicrobial Chemotherapy 75:1667-1670. doi: 10.1093/jac/dkaa114.

Zhou P, Yang XL, Wang XG, Hu B, Zhang L, Zhang W, Si HR, Zhu Y, Li B, Huang CL, Chen HD, Chen J, Luo Y, Guo H, Jiang RD, Liu MQ, Chen Y, Shen XR, Wang X, Zheng XS, Zhao K, Chen QJ, Deng F, Liu LL, Yan B, Zhan FX, Wang YY, Xiao GF, Shi ZL (2020b) A pneumonia outbreak associated with a new coronavirus of probable bat origin. Nature 579:270-273. doi: 10.1038/s41586-020-2012-7.

Zou L, Ruan F, Huang M, Liang L, Huang H, Hong Z, Yu J, Kang M, Song Y, Xia J, Guo Q, Song T, He J, Yen HL, Peiris M, Wu J (2020) SARS-CoV-2 Viral Load in Upper Respiratory Specimens of Infected Patients. The New England Journal of Medicine 382:1177-1179. doi: 10.1056/NEJMc2001737. 